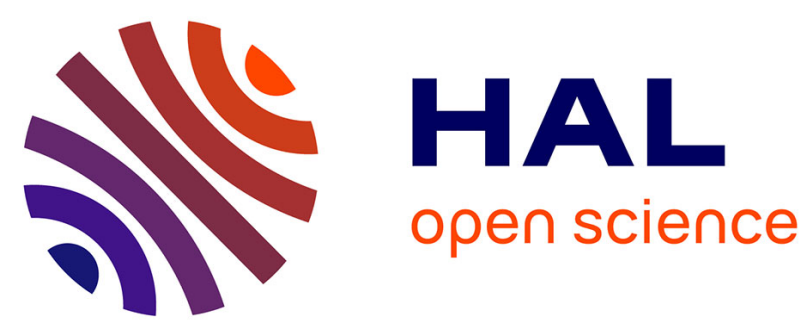

\title{
A study to constrain the geometry of an active fault in southern Italy through borehole breakouts and downhole logs.
}

\author{
Simona Pierdominici, Maria Teresa Mariucci, Paola Montone
}

\section{To cite this version:}

Simona Pierdominici, Maria Teresa Mariucci, Paola Montone. A study to constrain the geometry of an active fault in southern Italy through borehole breakouts and downhole logs.. Journal of Geodynamics, 2011, 52 (3-4), pp.279. 10.1016/j.jog.2011.02.006 • hal-00780027

\section{HAL Id: hal-00780027 \\ https://hal.science/hal-00780027}

Submitted on 23 Jan 2013

HAL is a multi-disciplinary open access archive for the deposit and dissemination of scientific research documents, whether they are published or not. The documents may come from teaching and research institutions in France or abroad, or from public or private research centers.
L'archive ouverte pluridisciplinaire HAL, est destinée au dépôt et à la diffusion de documents scientifiques de niveau recherche, publiés ou non, émanant des établissements d'enseignement et de recherche français ou étrangers, des laboratoires publics ou privés. 


\section{Accepted Manuscript}

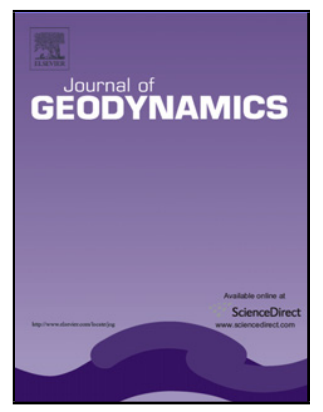

Title: A study to constrain the geometry of an active fault in southern Italy through borehole breakouts and downhole logs.

Authors: Simona Pierdominici, Maria Teresa Mariucci, Paola Montone

PII:

S0264-3707(11)00042-1

DOI: doi:10.1016/j.jog.2011.02.006

Reference: GEOD 1049

To appear in: $\quad$ Journal of Geodynamics

Received date: $\quad 27-9-2010$

Revised date: $\quad$ 15-2-2011

Accepted date: $\quad$ 19-2-2011

Please cite this article as: Pierdominici, S., Mariucci, M.T., Montone, P., A study to constrain the geometry of an active fault in southern Italy through borehole breakouts and downhole logs., Journal of Geodynamics (2010), doi:10.1016/j.jog.2011.02.006

This is a PDF file of an unedited manuscript that has been accepted for publication. As a service to our customers we are providing this early version of the manuscript. The manuscript will undergo copyediting, typesetting, and review of the resulting proof before it is published in its final form. Please note that during the production process errors may be discovered which could affect the content, and all legal disclaimers that apply to the journal pertain. 
1 A study to constrain the geometry of an active fault in southern Italy through borehole

2 breakouts and downhole logs.

3

4 Simona Pierdominici ${ }^{1}$, Maria Teresa Mariucci ${ }^{1}$ and Paola Montone ${ }^{1}$

5

$6{ }^{1}$ Istituto Nazionale di Geofisica e Vulcanologia, Sezione di Sismologia e Tettonofisica, via di

7 Vigna Murata, 605, Rome, Italy

8

9 Submitted to: Journal of Geodynamics

10

11

12 Corresponding author:

13 Simona Pierdominici

14 Istituto Nazionale di Geofisica e Vulcanologia

15 Via di Vigna Murata 605

1600143 Rome, ITALY

17 Tel: +39-06-51860576

18 Fax: +39-06-51860507

19 E-mail address: simona.pierdominici@ingv.it

20 


\section{Abstract}

Identification of an active fault and the local versus regional present-day stress field in the Irpinia region (southern Apennines) have been performed along a 5900m deep well (San Gregorio Magno 1) by a detailed breakout and geophysical log analysis. The selected area is characterized by diffuse low magnitude seismicity, although in historical times moderate to large earthquakes have repeatedly struck it. On $23^{\text {rd }}$ November 1980 a strong earthquake $(\mathrm{M}=6.9)$ nucleated on a $38 \mathrm{~km}-$ long normal fault, named Irpinia fault, producing the first unequivocal historical surface faulting ever documented in Italy. The analysis of stress-induced wellbore breakouts shows a direction of minimum horizontal stress $\mathrm{N} 18^{\circ} \pm 24^{\circ}$, fairly consistent with the regional stress trend $\left(\mathrm{N} 44^{\circ} \pm 20^{\circ}\right)$. The small discrepancy between our result and the regional stress orientation might be related to the influence of local stress sources such as variations of the Irpinia fault plane orientation and the presence of differently oriented active shear zones. This paper shows for the first time a detailed analysis on the present-day stress along a well to identify the Irpinia fault at depth and constrain its geometry.

Key words: Borehole breakout, geophysical log, present-day stress field, seismogenic fault, southern Apennines, Italy.

\section{Introduction}

This paper is mainly devoted to the present-day stress field study performed in a high seismic hazard area of southern Italy (Cinti et al., 2004; Faenza and Pierdominici, 2007) in order to assess a methodology to identify and constrain active faults at depth along deep wells.

The present-day stress state can be assessed by different techniques, including the analysis of: (i) borehole breakouts, (ii) focal mechanism solutions, (iii) exposed active fault segments, (iv) well cores, and (v) crustal deformation and differential strain (Ding and Zhang, 1991; Zoback, 1992; Seto et al., 1998). Breakouts are used as indicators of the direction of maximum and minimum 
horizontal stress $\left(\mathrm{S}_{\mathrm{Hmax}}\right.$ and $\mathrm{S}_{\mathrm{hmin}}$, respectively) and correspond to observation points along deep wells (Bell and Gough, 1979; Zoback et al., 1985). Many studies have shown that the present-day stress orientation in a region is quite homogeneous and independent of the stratigraphy and depth (e.g. Plumb and Cox, 1987; Castillo and Zoback, 1994), whereas along a borehole the breakout orientations can change due to the presence of active faults (Barton and Zoback, 1994; Wu et al., 2007). As reported by several authors stress perturbations have been associated to open fractures and to active faults which have slipped recently (Bell et al., 1992; Shamir and Zoback, 1992; Barton and Zoback, 1994; Mariucci et al., 2002; Wu et al., 2007). Moreover, shear zones at depth usually show physical properties different from the nearby undamaged rock and downhole logs can record these features.

In this paper we have analysed the present-day stress along and around a deep well and tried to identify at depth some shear zones and the seismogenic fault, named Irpinia, located in the southern Apennines. This fault is related to the $1980 \mathrm{Ms}=6.9$ Irpinia earthquake, and represents the first unequivocal surface faulting ever documented in Italy. Its geometry is not well constrained by geophysical exploration and aftershock data analysis because this tectonic structure is relatively a young fault that has not yet developed enough cumulated vertical slip to be clearly resolved by seismic reflection profiles (Pantosti and Valensise, 1993; Improta et al., 2003; Cippitelli, 2007; Patacca, 2007; Figure 1). This paper shows for the first time a detailed analysis on the present-day stress nearby the seismogenic fault in the context of the overall setting. The Irpinia fault trace is located $\sim 1.3 \mathrm{~km}$ westward from the well San Gregorio Magno 1 (herein named SGM1), and according to its geometry, the well should cut off it. If this is true, the main observation of Barton and Zoback, (1994) that stresses reorient close to faults should be verified. The idea is to study the present-day stress in the SGM1 well to identify the possible stress perturbations close to the Irpinia fault. Then, borehole breakouts, downhole log data and tectonic structures along the deep well SGM1 have been analysed. 


\section{Geological-structural setting and regional seismicity}

The southern Apennine belt is part of the Alpine orogens of the Mediterranean area, developing from the interaction between the converging Africa-Apulian and European plates since Late Cretaceous time, (e.g. D’Argenio et al., 1973; Dewey et al., 1989; Mazzoli and Helman, 1994 and references therein; Butler et al., 2004). The southern Apennines are a NE-verging fold-andthrust belt that began to grow mainly since the lower Miocene (Bonardi et al., 1988; Patacca et al., 1990) due to deformation of the Adriatic subducting margin. The thrust belt is characterized by allochthonous units derived from both carbonate platform and pelagic basin successions (Apenninic Platform and Lagonegro Basin, respectively), which are stratigraphically overlain by Neogene foredeep and wedge-basin deposits (Miocene and Pliocene successions). These units are completely detached from their original substratum and transported onto the foreland sequence of the Apulian carbonate Platform (e.g. Doglioni et al., 1996; Mazzoli et al., 2004).

In the early Pliocene (Scandone et al., 2003), the entire pile of nappes overthrusts the Apulian carbonate platform giving rise to a complex duplex system (e.g., Mostardini and Merlini, 1996; Cello et al., 1987, 1989; Casero et al., 1988; Ascione et al., 2003; Patacca and Scandone, 2007). In this tectonic context, the thrust sheet emplacement moved following the opening of the Tyrrhenian back-arc basin (Patacca et al., 1990) as a consequence of the roll-back of the subducting Adriatic plate (Malinverno and Ryan, 1986; Doglioni, 1991). Only in the middle-late Pliocene, the Apulia Platform underwent shortening processes that created duplexing in the deep-seated carbonates and displacement of the overlying allochthonous sheets (Patacca and Scandone, 2007). The processes of thrusting and Adriatic-verging nappe transport have been active on the eastern side until the lower part of middle Pleistocene (Casero et al., 1988; Patacca et al., 1990; Roure et al., 1991; Cinque et al., 1993; Pieri et al., 1997; Patacca and Scandone, 2001), when the flexure-hinge retreat in the Adriatic plate suddenly stopped (Patacca and Scandone, 2007). 
For further information on the geological and structural setting, the reader is referred to the wide existing literature (e.g., Casero et al., 1991; Patacca and Scandone, 1989; 2004; Lavecchia, 1988; Pescatore et al., 1999; Galadini et al., 2000; Giano et al., 2000; Lentini et al., 2002; Valensise and Pantosti, 2001; Schiattarella et al., 2003; Scrocca et al., 2007).

Concerning the seismicity, the southern Apennines are characterized by recent low magnitude seismic events, punctuated by large historical earthquakes that shook the area in the past (CPTI Working Group, 2004) (Figure 2). Strong historical events (Io=IX-X) have been well documented since 1500: 1561-Vallo di Diano; 1694-Irpinia; 1826-Tito; 1831-Rivello; 1836-Lagonegro; 1851Basilicata; 1857-Val d'Agri; 1930-Irpinia; 1980-Irpinia (Esposito et al., 1988; Marturano et al., 1988; Porfido et al., 1988; CPTI Working Group, 2004).

The instrumental seismicity, recorded by the Istituto Nazionale di Geofisica e Vulcanologia (INGV) since 1981 is characterized by magnitudes generally lower than 4.0 (Castello et al., 2008). Only a few isolated seismic sequences hit the southern Apennines in the last years (Figure 2, Table 1). In 1990-1991 the Potenza area was shaken by a seismic sequence ( $\mathrm{Mw}=5.7$ and $\mathrm{Mw}=5.2)$ which occurred from about 2 to $25 \mathrm{~km}$ depth with the mainshocks showing E-W dextral strike-slip mechanism (Azzara et al., 1993; Ekström, 1994; CPTI Working Group, 2004; Di Luccio et al., 2005); in 1996 the Irpinia area was hit by a seismic sequence characterized by normal faulting mechanisms with a mainshock $(\mathrm{Mw}=5.1)$ at $8 \mathrm{~km}$ depth (Cocco et al., 1999; Cucci et al., 2004); in 1998 normal faulting earthquakes occurred in the north Pollino area with Mw=5.6 (Michetti et al., 2000; Pondrelli et al., 2002) and in 2002 the Melandro-Pergola basin was affected by $\mathrm{Mw}=4.1$ earthquake at a depth of 9km (Cucci et al., 2004; Frepoli et al., 2005). The seismicity is mainly placed along the axial part of the belt, within the shallow crust, showing NE-SW T-axes with prevailing normal faulting focal mechanisms (Gasparini et al., 1985; Frepoli and Amato, 2000; Pondrelli et al., 2006; Maggi et al., 2009 among many others). As mentioned above, this trend is also coherent with the active stress field (Figure 2) inferred from geological and borehole breakout data (e.g., Amato et al., 1995; Montone et al., 2004). 


\subsection{The 1980 M6.9 Irpinia earthquake}

124

125

126

127

128

129

130

131

132

133

134

135

136

137

138

139

140

141

142

143

144

145

146

147

In the last century, the most important and largest seismic event in the southern Apennines was the Irpinia earthquake that occurred on November 23, 1980 with Ms=6.9 (Boschi et al., 1993). It was one of the most disastrous events in Italy, causing the death of about 3000 people and the total destruction of 15 towns within a radius of nearly $50 \mathrm{~km}$. This earthquake nucleated at a depth of $10-$ $12 \mathrm{~km}$ (Westaway and Jackson, 1987) with a focal mechanism characterized by NW-SE normal faulting planes and by a moment tensor of $2,4 * 10^{19} \mathrm{Nm}$ (Giardini, 1993) (Figure 3a). The aftershock distribution indicated that the area of the earthquake source was about $14 \times 40 \mathrm{~km}^{2}$ providing also information on source geometry (Deschamps and King, 1980; Amato and Selvaggi, 1993) and on the relationship between crustal structure and faulting mechanism (Chiarabba and Amato, 1994; Improta et al., 2003). However, the 3D locations from local earthquake tomography did not allow constraining the fault geometry at depth accurately (Deschamps and King, 1984).

The Irpinia earthquake consists of three subevents, at 0 s (the mainshock), at $\sim 20$ s and $\sim 40$ s from the mainshock (Bernard and Zollo, 1989). Associated to the 0s and 20s events, a $38 \mathrm{~km}$ long rupture at the surface was partially recognized by Westaway and Jackson (1984) and then totally defined by Pantosti and Valensise (1990). Its mean strike is $\mathrm{N} 308^{\circ}$, with a $60^{\circ}-70^{\circ}$ dip to the northeast with an average value of normal slip of $61 \mathrm{~cm}$ along the fault (Pantosti et al., 1993) and a total vertical throw of about 50m in the last 150krs (Ascione et al., 2003; Improta et al., 2003). Pantosti and Valensise (1990, 1993) divided the 1980-surface rupture into 3 main segments on the basis of geological and geomorphological observations of the scarp, which is clearly linked to the coseismic deformation at depth. These 3 scarp strands are, from northwest to southeast: the Cervialto, the Marzano-Carpineta and the San Gregorio Magno (Figure 3a), separated by two surface faulting gaps (the Sele and the San Gregorio Magno gap). The first shock (at $0 \mathrm{sec}$ ) is associated both to the Marzano-Carpineta segment and to the Cervialto scarp (approximately 8-10 km long). The second event happened after 20s along a $8 \mathrm{~km}$ San Gregorio Magno segment. Considering only seismological data, the last event 
148 (40s) is supposed to be located on an antithetic, SW-dipping branch fault (Ofanto fault segment)

149 (Improta et al., 2003) in front of the Cervialto and Marzano-Carpineta structures (Figure 3a); no 150 evidence of surface rupture exists for this event.

\section{San Gregorio Magno 1 well}

\subsection{Stratigraphy and structural outline}

The SGM1 well is located at $797 \mathrm{~m}$ elevation near the Marzano-Carpineta fault scarp (Figure

155

156

157

158

159

160

161

162

163

164

165

166

167

168

169

170

171

172

173

3b). It was drilled by British Gas RIMI in 1996-1997 down to a depth of 5900m with the goal of reaching a structural high in the Apulia carbonate Platform, which is generally a target of the oil industry in the southern Apennines, imaged by commercial and deep reflection profiles (Patacca and Scandone, 2007)) and gravity data modelling (Improta et al., 2003). The SGM1 well (Patacca, 2007) crossed three main tectonic units bounded by two thrust faults at $2280 \mathrm{~m}$ and $3377 \mathrm{~m}$ and different lithological units (Figure 4a).

According to Patacca (2007), the well penetrates 2280m of the Mesozoic carbonates of the Alburno-Cervati Unit (part of the Apenninic carbonate Platform succession), $\sim 1100 \mathrm{~m}$ of the Lagonegro Unit II (part of Lagonegro basinal succession) and $2600 \mathrm{~m}$ of the Apulian carbonate Platform. The first Unit is composed of: i) "lime breccias" (early Cretaceous-Jurassic), typical of slope environments and characterized by calcirudites and calcarenites, and ii) Dolomia Principale Formation (late Triassic), deposited in a tidal flat environment and characterized by dolomites and dolomitic limestones. The underlying Lagonegro Unit II, deposited in a deep-marine basin, consists of: i) the Galestri Formation (early Cretaceous), that is mainly formed of claystones and shales and subordinate calcilutites and calcarenites; ii) the Scisti Silicei Formation (Jurassic to Rhaetian), containing calcarenites and radiolarites and subordinate siliceous shales $(2735-3070 \mathrm{~m})$, and in the lower part claystones and shales with subordinate calcarenites and calcilutites (3070-3200m); finally iii) the M. Facito Formation (early-middle Triassic), formed by shales, sandstones, siltstones and siliciclastic calcarenites, subordinate radiolarites and limestones. The deepest tectonic unit, the 
174

175

176

177

178

179

180

181

182

183

184

185

186

187

188

189

190

191

192

193

194

195

196

197

198

199

Apulia, includes: "wildflysch" (middle Miocene to early Pliocene), siciliclastic flysch deposits derived from the Apennines nappes deposited in foredeep basin; Gessoso Solfifera Formation (Messinian) characterized by anhydrites and evaporitic limestones, typical of evaporitic carbonate ramp; "lime breccias" (upper Cretaceous) typical of slope environment consisting of calcarenites, calcilutites and calcirudites; "shallow-water carbonates" (Dogger-upper Cretaceous) deposited in a shelf environment. Besides the two thrusts, following the reconstruction of Patacca (2007), the well also encountered a system of SW-dipping normal faults at 440m and 3198m (Figure 4a). As the surface rupture of the Irpinia fault is located $\sim 1.3 \mathrm{~km}$ westward from the well, according to its geometry (N308 striking, $60^{\circ}-70^{\circ}$ northeast dipping), the borehole should intersect the fault within the depth range $\sim 2300-3800$ m (Figure $4 \mathrm{a}$ ). As a matter of fact, the fault has not been unequivocally recognized from the available data, either on stratigraphic logs or on seismic profiles. As mentioned in the introduction, one possible explanation is that the relatively young fault has not yet developed enough cumulated vertical slip to be clearly resolved by seismic reflection profiles (Pantosti and Valensise, 1993; Improta et al., 2003; Cippitelli, 2007; Patacca, 2007). For this reason we have jointly used different methods, including borehole breakouts and downhole logs, to identify the possible active shear zones and the Irpinia fault.

\subsection{Borehole breakout data}

Method

Borehole breakout analysis is an important tool for the evaluation of stress patterns in the uppermost crust (Bell and Gough, 1979; Zoback and Zoback, 1980, 1991; Zoback et al., 1985, 1989; Plumb and Cox, 1987). Breakouts fill the gap between data from earthquake focal mechanisms and surface measurements (e.g. active faults, extensional fractures and strain release measurements): they are the result of localized conjugate compressive shear failures that develop along deep wells in an anisotropic stress field with a triangular shape in cross-section. The shear planes are tangential to the circumference of the borehole and identify breakout zones parallel to the 
direction of the $S_{\text {hmin }}$. The first breakout develops in the borehole very soon after the passage of the drill bit and continues to propagate along the axis of the borehole and into the formation (Bell and Gough, 1983). Mechanisms that explain the formation of these features have been extensively examined in the literature (Babcock, 1978; Bell and Gough, 1979; Zoback et al., 1985; Haimson and Heirrick, 1986; Zheng et al., 1989; Amadei and Stephansson, 1997).

Borehole breakouts are identified from four-arm caliper readings collected routinely with conventional dipmeter logging tools. Different borehole geometries are defined as: i) "in-gauge", if the hole has the dimensions of the drill bit called bit size; ii) "breakout zone", when one diameter is elongated and the orthogonal one has the bit size dimension; iii) "key seat", when the drill-string wear causes a pear-shaped borehole with an artificial elongation at the low side of the well. It occurs when the borehole is highly deviated from vertical; iv) "washout", an enlargement of the borehole in an "over-gauge hole" (Plumb and Hickmann, 1985). To obtain the average direction and standard deviation of the least horizontal stress in the well, the statistical method from Mardia (1972) has been applied in this study. Results are shown as rose diagrams scaled by length, and a quality factor is assigned to each well (from $\mathrm{A}=$ highest quality to $\mathrm{E}=$ lowest quality) according to the criteria used for the World Stress Map (Heidbach et al., 2008), first suggested by Zoback (1992).

\section{Analysis}

The breakout analysis of SGM1 well has been performed by four-arm caliper log data from $1200 \mathrm{~m}$ to $5900 \mathrm{~m}$ depth with two gaps $(2645-2945 \mathrm{~m}$ and $4775-4950 \mathrm{~m})$. The results of the investigation showed: a) key seats between 1200 and 2000 m; b) no breakout between 5585 and 5900 and c) breakouts between 2000 and 5585m.

The result of the entire well shows a cumulative breakout length of $675 \mathrm{~m}$ with an average $\mathrm{S}_{\mathrm{hmin}}$ orientation of $\mathrm{N} 18^{\circ}$ and a standard deviation of $24^{\circ}$ (Figure $4 \mathrm{~h}$ ), with a data quality C (according to World Stress Map criteria; Heidbach et al., 2008). 
A more detailed breakout analysis, considering all the data quality, has been performed for each

226

lithological and tectonic unit to understand the scattering of breakout data (Figure $4 \mathrm{~d}, \mathrm{f}, \mathrm{g}$ and Table 2). We have identified a breakout zone from 2000 to $2075 \mathrm{~m}$ in the Dolomia Principale (belonging to the Alburno-Cervati tectonic unit) $\mathrm{N} 348^{\circ}$ oriented for a $75 \mathrm{~m}$ total length. The Lagonegro II tectonic unit is characterized by a $\mathrm{S}_{\mathrm{hmin}}$ orientation $\mathrm{N} 38^{\circ} \pm 33^{\circ}$ and a length of $365 \mathrm{~m}$ with five breakout zones related to: the Galestri Fm. with $\mathrm{S}_{\mathrm{hmin}} \mathrm{N} 310^{\circ}$ oriented and a total length of $125 \mathrm{~m}$; the Scisti Silicei Fm. N41 ${ }^{\circ}$ and a total length of $165 \mathrm{~m}$, and the M. Facito Unit with $\mathrm{S}_{\mathrm{hmin}} \mathrm{N} 33^{\circ}$ trending and $75 \mathrm{~m}$ long. The Apulia tectonic unit is characterized by a $\mathrm{S}_{\mathrm{hmin}}$ orientation $\mathrm{N} 7^{\circ} \pm 28^{\circ}$ for a total length of $607 \mathrm{~m}$ : in the Wildflysch $\mathrm{S}_{\mathrm{hmin}}$ is $\mathrm{N} 325^{\circ}$ oriented (total length of $245 \mathrm{~m}$ ) and in the Shallow-water carbonate unit is $\mathrm{N} 15^{\circ}$ (total length of $362 \mathrm{~m}$ ) (Table 2). No breakouts have been found in the Gessoso Solfifera and Lime Breccias units.

As the regional stress field is well constrained in the area $\left(\mathrm{S}_{\mathrm{hmin}} \mathrm{N} 44^{\circ} \pm 20^{\circ}\right)$ (Montone et al., 1997; Montone et al., 2004), we believe it is possible to distinguish, along the well, anomalous stress directions departing from the regional trend and associate them with shear zones intersected by the drilling (Shamir and Zoback, 1992; Barton and Zoback, 1994; Wu et al., 2007). Barton and Zoback (1994) point out that the stress field rotates in proximity to an active fault due to small slip increments on the fault, possibly induced by the tectonic movement or due to an increase of pore pressure on the fault when drilling through it. With the purpose of identifying the Irpinia fault, the stress field detected from SGM1 has been compared to the regional stress orientation. Any deviation from the regional value has been considered as a local rotation of the stress field - if the breakout orientation deviates from the regional one more than $15^{\circ}$ - and is shown as clockwise or anticlockwise rotation (Figure 4e). Along the SGM1 well, anomalously oriented breakouts occur in five intervals: $2000 \mathrm{~m}-2650 \mathrm{~m}, 3450 \mathrm{~m}-3855 \mathrm{~m}, 4350-4560 \mathrm{~m}$, around $4800 \mathrm{~m}$ and around $5500 \mathrm{~m}$ (Figure 4d-e).

As observed in other deep wells, when the breakout trend abruptly changes it is possible to identify faults and/or fracture zones otherwise difficult to recognize by seismic reflection data and drill 
cutting analysis (Bell et al., 1992). We have distinguished four zones that separate different breakout orientations (Figure 4): from $2650 \mathrm{~m}$ to $2950 \mathrm{~m}$ (zone 1), $3275 \mathrm{~m}$ to $3450 \mathrm{~m}$ (zone 2), $3855 \mathrm{~m}$ to $4320 \mathrm{~m}$ (zone 3 ), and $5057 \mathrm{~m}$ to $5460 \mathrm{~m}$ (zone 4$)$.

Considering the uncertainty of the fault geometry, three of the anomalous zones (zone 1,2 and 3) are located around the area where the well is supposed to crosscut the Irpinia fault: in fact according to most authors (e.g., Boschi et al., 1981), the Irpinia fault has a dip between $60^{\circ}$ to $70^{\circ}$ corresponding to a depth of intersection with SGM1 approximately between $2300 \mathrm{~m}$ to $3800 \mathrm{~m}$ (Figure 4).

\section{Breakout versus downhole geophysical data}

The stress field along the SGM1 well has been studied using two approaches. First, we have analysed the borehole breakout data to obtain information on the present-day stress field. Second, we have used these data and the downhole logs to identify possible shear zones and the Irpinia fault itself. Shear zones at depth usually show physical properties different from the nearby undamaged rock and these features can be recorded by downhole logs. As by now observed in other drilled active faults (Wu et al., 2007; Wu et al., 2008) the shear zones correspond to the most significant changes in sonic and resistivity curves with respect to their average trend at depth.

Assuming the SGM1 well crossed the Irpinia fault we have analyzed three downhole curves (gamma ray, resistivity and sonic; Figure 5) in order to detect their anomalous physical properties with respect to overall value characterizing each lithology. For our analysis we have used an extremely detailed stratigraphic log (courtesy of Etta Patacca and Paolo Scandone) that allowed us to recognize and discard the anomalies related to the small-scale lithological variations and to the identified faults. In fact, according to this interpretation those faults are westward dipping, whereas the Irpinia fault dips toward east.

The remaining sectors showing significant changes in downhole logs are located at the following depths (Figure 5): around 2350m (sector A), around 3100m (sector B) with two small 
areas, around 3800m (sector C), around 4300m (sector D) and around 4700m (sector E). Considering the Irpinia fault geometry $\left(60^{\circ}-70^{\circ}\right.$ dipping) we can exclude the two deepest sectors (D and E). Particularly, in the sector A the sonic curve shows a decrease with respect its mean value (Figure 5) while the other curves do not seem to show any anomaly; in sector B we have identified two small zones showing anomalous peaks in all the curves (a decrease in gamma ray and sonic logs and an increase in resistivity, Figure 5). Finally, in sector $\mathrm{C}$ we have identified a well defined peak showing an increase in the sonic curve and a decrease in the resistivity curve trend (Figure 5). All these sectors correspond to washout zones (Figure 5b) that also support the presence of shear zones. In fact, when a borehole crosses a highly fractured area, the stress concentration enhances the effect of natural fractures that are mechanically weaker, and can easily produce collapse of the wellbore wall, detected as enlargements of the borehole size. Only sectors $\mathrm{A}$ and $\mathrm{C}$ are located within the previously identified five anomalous breakout intervals, whereas sector B is located where breakouts are consistent with the regional $\mathrm{S}_{\mathrm{hmin}}$ orientation. As mentioned before, abrupt breakout rotations indicate the presence of active shear zones. For this reason we suggest that the Irpinia fault is located around $2350 \mathrm{~m}$ (sector $\mathrm{A}$ ) or around $3800 \mathrm{~m}$ (sector C). In both zones we have more confident data revealing not only abrupt breakout rotations ( NW-SE oriented) but also washout presence, geophysical log anomalies not directly connected to the lithology, and consistency with the fault dip deduced from focal mechanisms and surface data.

\section{Discussion and conclusion}

The stress analysis has allowed us to constrain the $\mathrm{S}_{\mathrm{hmin}}$ orientation along the well $\left(\mathrm{N} 18^{\circ} \pm 24^{\circ}\right)$, suggesting that it is moderately consistent with the neighbouring regions (Figure 6). The slight difference between the regional stress field $\left(\mathrm{S}_{\mathrm{hmin}}=\mathrm{N} 44^{\circ} \pm 20^{\circ}\right)$ and the achieved SGM1 $\mathrm{S}_{\mathrm{hmin}}$ is due to the presence of $\sim \mathrm{N}-\mathrm{S} \mathrm{S}_{\mathrm{hmin}}$ orientations in the deepest part of the well, mainly within the Apulia tectonic unit (Figure $4 \mathrm{~g}$ and Figure 6). In Figure 6 breakouts are shown as rose diagrams instead of average $S_{h m i n}$ orientations; in fact we believe that the average $S_{h m i n}$ orientations are more appropriate 
303 for regional tectonic reconstructions, whereas for local tectonic interpretations it is preferable to 304 consider rose diagrams, where it is easier to resolve the contribution of possible different 305 orientations within the same well.

306 Two main directions are observable not only in SGM1 but also in other breakout solutions (even 307 of higher quality, A or B) along the belt and the foredeep. A N-S orientation has been recognized 308 also in another deep well located in the northern part of the Irpinia area (Figure 6) and could be 309 linked to the presence of $\sim \mathrm{E}-\mathrm{W}$ tectonic structures or to the changing trend of the NW-oriented 310 faults. Actually, it is a common feature of a fault plane showing variable orientations that can 311 correspond to slight deviations in the local principal stress orientations. The inferred $\mathrm{S}_{\mathrm{hmin}}$ orientation 312 is not exactly at $90^{\circ}$ with respect to the $\mathrm{N} 308^{\circ}$ Irpinia fault mean direction, but it is fairly consistent 313 with the "zig-zagging" trend of the fault (Pantosti and Valensise, 1993) and with the local tectonic 314 structures displaying $\sim$ E-W directions (Caiazzo et al., 1992; Ascione et al., 2003). In detail, in this 315 area there is interference between the $\mathrm{N} 150^{\circ}$ and $\mathrm{N} 110^{\circ}-100^{\circ}$ trends relative to the Marzano316 Carpineta structure and Mt. Ogna fault respectively, both reactivated during the late Quaternary 317 (Ascione et al., 2003).

318 Concerning seismological data, in correspondence of the Irpinia area a lot of earthquake focal mechanisms (Cocco et al., 1999; Cucci et al., 2004; Frepoli et al., 2005; Maggi et al., 2009) exhibit 320 both normal faulting and strike slip mechanisms (Figure 6). Particularly, the fault plane solutions 321 closer to the well clearly show $\sim \mathrm{N}-\mathrm{S}$ oriented T-axis, on $\sim \mathrm{E}-\mathrm{W}$ nodal planes (Figure 6 and Table 1, 322 solutions from 20 to 23 ), which fit the deepest results of the breakout analysis.

Then, we hypothesize that the localized stress rotations along the SGM1 well probably result 324 from slip on nearby faults indicating active deformation in the crust. Also the geophysical logs 325 show significant anomalies in the physical properties in correspondence of two hypothesized major 326 active shear zones: at 2350m (sector A) and around 3800m (sector C), depths where we suppose the 327 Irpinia fault is located. 
Then, we propose some possible hypotheses in terms of general geometry of the Irpinia fault, especially concerning its dip, segmentation or continuity (Figure 7). Starting from the information that the fault dips $60^{\circ}$ at $10-12 \mathrm{~km}$ depth, as inferred from the focal mechanism solution of the 1980 Irpinia earthquake, and taking into account the lower and upper bounds of the surface fault dip $\left(60^{\circ}\right.$ and $70^{\circ}$ ) we obtain four different options. If the well crosses the fault in the sector A (i.e. the fault dip is around $60^{\circ}$ ) we can suppose: 1) a straight fault plane $60^{\circ}$ dipping from surface to focal depth (red line in Figure 7); or 2) a fault plane changing dip from $70^{\circ}$ at surface to $60^{\circ}$ immediately below (blue line in Figure 7). Whereas, if sector $\mathrm{C}$ is the true hole-fault intersection (i.e. fault dip around $70^{\circ}$ ) we can have: 3) an irregular fault plane trend (like a "vertical segmentation") with two dip changes, from $60^{\circ}$ to $70^{\circ}$ at few kilometres from the surface and from $70^{\circ}$ to $60^{\circ}$ around $10 \mathrm{~km}$; or 4 ) a $70^{\circ}$ dipping fault changing to $60^{\circ}$ down to focal depth (yellow line in Figure 7). The first two hypotheses (numbers 1 and 2) differ only for the dip at surface and then can be considered as one hypothesis. Among these different hypotheses we believe that the number 3 is the less reliable considering its geometry and also it is very similar to the hypothesis number 4 at depth. Then we concentrate on the last hypothesis that agrees with the fault geometry proposed by Amato and Selvaggi (1993) based on the seismicity distribution and earthquake focal mechanisms. Occurrence

344 of the fault in sector $\mathrm{C}$ is also consistent with the idea of stress decoupling due to the Irpinia fault, as supported by breakout orientations along the well that show a prevailing NNE-SSW direction

346 (immediately below sector C) and $\sim \mathrm{NS}$ in the deepest part of the well (4300-5600m; Figure 4, rose 347 plot of column f). We believe that this sector has a slightly higher degree of probability, with respect 348 to sector A, to be the real location of Irpinia fault along SGM1 well and then, the yellow line the most probable geometry of the fault (Figure 7).

350 The identification of fault geometry is an important factor for the characterization of the seismic 351 behaviour and therefore the seismic hazard assessment of an area. The seismic behaviour of a fault 352 can be considered both in space and in time. In the first case, the location and the geometry of the 353 active faults influence the interactions with the surrounding faults that may accumulate stress or 
initiate. This observation is consistent with substantial release of accumulated strain energy during earthquakes and a redistribution of stress in adjacent areas (e.g., Marzocchi et al., 2009). In the second case, the seismic behaviour of a fault is studied by examining the historical seismicity and the paleoseismological records to estimate recurrence intervals along different fault segments.

In this paper, the most significant result is that using downhole log and borehole breakout data is possible to constrain the most likely location of an active fault at depth.

\section{Acknowledgement}

This work was partially funded by the Italian Ministry of University and Research in the framework of Project FIRB "Research and Development of New Technologies for Protection and Defense of Territory from Natural Risks", W.P. C3 "Crustal Imaging in Italy", coordinated by P. Montone. Many thanks are due to the reviewers for their precious suggestions which greatly improved the paper.

\section{References}

Amadei, B., Stephansson, O., 1997. Rock stress and its measurement. Chapman and Hall, London, p. 490.

Amato, A., Selvaggi, G., 1993. Aftershock location and P-velocity structure in the epicentral region of the 1980 Irpinia earthquake. Ann. Geofis. 36, 3-15.

Amato, A., Montone, P., Cesaro, M., 1995. State of stress in southern Italy from borehole breakout and focal mechanisms data. Geophys. Res. Lett. 22, 3119-3122.

Ascione, A., Cinque, A., Improta, L., Villani, F., 2003. Late Quaternary faulting within the Southern Apennines seismic belt: new data from Mt. Marzano area (Southern Italy). Quaternary International $101-102,27-41$.

Azzara, R., Basili, A., Beranzoli., L., Chiarabba, C., Di Giovambattista, R., Selvaggi, G., 1993. The seismic sequence of Potenza (May 1990). Ann. Geofis. 36 (1), 237-243.

Babcock, E.A., 1978. Measurement of subsurface fractures from dipmeter logs. AAPG Bulletin 62 (7), 1111-1126. Reprinted in 1990, in Foster, N.H., and Beaumont, E.A., eds., Formation evaluation II-log-interpretazion: AAPG Treatise of Petroleum Geology Reprint Series n. 17, pp. 457-472. 
Barton, C.A., Zoback, M.D., 1994. Stress perturbations associated with active stress faults penetrated by boreholes: Possible evidence for near-complete stress drop and the a new technique for stress magnitude measurements. J. Geophys. Res. 99 (B5), 9373-9390.

Bell, J.S., Gough, D.I., 1979. Northeast-southwest compressive stress in Alberta: evidence from oil wells. Earth and Plan. Sc. Lett. 45, 475-482.

Bell, J.S., Gough, D.I., 1983. The use of borehole breakout in the study of crustal stress, in Hydraulic fracturing stress measurements. Edit by D.C., National Academy press, Washington.

Bell, J.S., Caillet, G., Adams, J., 1992. Attempts to detect open fractures and non-sealing faults with dipmeter logs. Geological Society, London, Special Publications 65, 211-220, doi:10.1144/GSL.SP.1992.065.01.16.

Bernard, P., Zollo, A., 1989. The Irpinia (Italy) 1980 Earthquake: Detailed Analysis of a Complex Normal Faulting. J. Geophys. Res. 94, 1631-1648.

Bonardi, G., D’Argenio, B., Perrone, V., 1988. Carta geologica dell'Appennino meridionale alla scala 1:250.000. Mem. Soc. Geol. It. 41, 1341, 1 tav.

Boschi, E., Mulargia, F., Mantovani, E., Bonafede, M., Dziewonski, A.M., Woodhouse, J.H., 1981. The Irpinia earthquake of Novembre 23, 1980. Eos Trans. AGU 6, p. 330.

Boschi, E., Pantosti, D., Slejko, D., Stucchi, M., Valensise, G., 1993. Special issue on the meeting "Irpinia Dieci annAnni i Dopo", Sorrento 19-24 November 1990. Ann. Geofis. 36 (1), 353 pp, Editrice Compositori.

Butler, R.W.H., Mazzoli, S., Corrado, S., De Donatis, S., Di Bucci, D., Gambini, R., Naso, G., Nicolai, C., Scrocca, D., Shiner, P., Zucconi, V., 2004. Applying thick-skinned tectonic models to the Apennine thrust belt of Italy-Limitations and implications, in: K. R. McClay (Ed.), Thrust tectonics and hydrocarbon systems. AAPG Memoir 82, 647-667.

Caiazzo, C., Giovine, G., Ortolani, F., Pagliuca, S., Schiattarella, M., Vitale, C., 1992. Genesi ed evoluzione strutturale della depressione tettonica dell'Alta Valle del Sele (Appennino CampanoLucano). Studi Geologici Camerti 1, 245-255.

Casero, P., Roure, F., Endignoux, L., Moretti, C., Sage, L., Vially, R., 1988. Neogene geodynamic evolution of the Southern Apennines. Mem. Soc. Geol. It. 41 (1), 109-120.

Casero, P., Roure, F., Vially R., 1991. Tectonic framework and petroleum potential of the southern Apennines, In Generation, accumulation and production of Europe's hydrocarbons, edited by Spencer A.M., Spec. Publ. European Assoc. Petroleum Geosci. 1, 381-387.

Castello, B., Moschillo, R., Pignone, M., Vinci, S., Doumaz, F., Nostro, C., Selvaggi, G., 2008. Carta della sismicità in Italia 2000-2007. http://csi.rm.ingv.it/, 2008. 
Castillo, D.A., Zoback, M.D., 1994. Systematic variations in stress state in the southern San Joaquin Valley: inferences based on well-bore data and contemporary seismicity. Am. Ass. Petrol. Geol. Bull. 78 (8), 1257-1275.

Cello, G., Paltrinieri, W., Tortrici, L., 1987. Caratterizzazione strutturale delle zone esterne dell'Appennino molisano. Mem. Soc. Geol. It. 38, 155-161.

Cello, G., Martini, N., Paltrinieri, W., Tortorici, L., 1989. Structural styles in the frontal zones of the Southern Apennines, Italy: an example from the Molise district. Tectonics 8, 753-768.

Chiarabba, C., Amato, A., 1994. From tomographic images to fault heterogeneities. Ann. Geofis. 37 (6), 1481-1494.

Cinque, A., Patacca, E., Scandone, P., Tozzi, M., 1993. Quaternary kinematic evolution of the Southern Apennines. Relationships between surface geological features and deep lithospheric structures. Ann. Geofis. 36 (2), 249-260.

Cinti, F.R., Faenza, L., Marzocchi, W., Montone, P., 2004. Probability map of the next $\mathrm{M} \geq 5.5$ earthquakes in Italy. Geochem. Geophys. and Geosystems 5 (11), doi:10.1029/2004GC000724.

Cippitelli, G., 2007. The Crop-04 seismic profile. Interpretation and structural setting of the Agropoli-Barletta Geotraverse, in: Mazzotti, A., Patacca, E., Scandone, P. (Eds), Results of the CROP Project sub-project CROP04 southern Apennines (Italy), Boll. Soc. Geol. It., special issue 7, 267-281.

Cocco, M., Chiarabba, C., Di Bona, M., Selvaggi, G., Margheriti, L., Frepoli, A., Lucente, F.P., Basili, A., Jongmans, D., Campillo, M., 1999. The April 1996 Irpinia seismic sequence: evidence for fault interaction. J. of Seism. 3, 105-117.

CPTI Working Group, Catalogo parametrico dei terremoti Italiani, version 2004 (CPTI04), Istituto Nazionale di Geofisica e Vulcanologia, Bologna, 2004. (Available at http://emidius.mi.ingv.it/CPTI).

Cucci, L., Pondrelli, S., Frepoli, A,. Mariucci, M.T., Moro, M., 2004. A multidisciplinary approach for the characterization of the seismogenic sources in seismic gap areas: first results from the Pergola-Melandro basin and the Agri valley (Southern Italy). Geophys. J. Int. 156, 575-583, doi:10.1111/j.1365-246X.2004.02161.x.

D'Argenio, B., Pescatore, T., Scandone, P., 1973. Schema geologico dell'Appennino meridionale (Campania e Lucania). Atti Acc. Naz. Lincei, Quad. 183, 49-73.

Deschamps, A., King, G.C.P., 1980. The Campania Lucania (southern Italy) earthquake of November 23, 1980. Earth Planet. Sci. Lett. 62, 296-304.

Deschamps, A., King, G.C.P., 1984. Aftershocks of the Campania-Lucania (Italy) earthquake of 23 November 1980. Bull. Seismol. Soc. Am. 74, 2483-2517. 
Dewey, J.F., Helman, M.L., Turco, E., Hutton, D.H.W., Knott, S.D., 1989. Kinematics of the western Mediterranean, in: Coward, M.P., Dietrich, D., Park, R.G. (Eds.), Alpine Tectonics, Geological Society Special Publication 45, 265-283.

Di Luccio, F., Piscini, A., Pino, N.A., Ventura, G., 2005. Reactivation of deep faults beneath southern Apennines: evidence from the 1990-1991 Potenza seismic sequences. Terra Nova 17, 586590.

Ding, Y.C., Zhang, D.L., 1991. Application of rock acoustic emission in crustal stress measurement. J. of Rock Mechanics and Engineering 10 (4), 326-331.

Doglioni, C., 1991. A proposal of kinematic modelling for W-dipping subductions - possible applications to the Tyrrhenian-Apennines system. Terra Nova 3, 423-434.

Doglioni, C., Harabaglia, P., Martinelli, G., Mongelli, F., Zito, G., 1996. A geodynamic model of the Southern Apennines accretionary wedge. Terra Nova 8, 540-547.

Ekström, G., 1994. Teleseismic analysis of the 1990 and 1991 earthquakes near Potenza. Ann. Geofis. 37, 1591-1599.

Esposito, E., Luongo, G., Maturano, A.,. Porfido, S., 1988. I terremoti recenti dal 1980 al 1986 nell'Appennino meridionale. Mem. Soc. Geol. It. 41 (2), 1117-1128.

Faenza, L., Pierdominici, S., 2007. Statistical occurrence analysis and spatio-temporal distribution of earthquakes in the Apennines (Italy). Tectonophysics 439, 13-31, doi:10.1016/j.tecto.2007.02.019.

Frepoli, A., Amato, A., 2000. Fault-plane solutions of crustal earthquakes in southern Italy (19881995): seismotectonic implications. Ann. Geofis. 43, 437-467.

Frepoli, A., Cinti, F.R., Amicucci, L., Cimini, G.B., De Gori, P., Pierdominici, S., 2005. Pattern of seismicity in the Lucanian Apennines and foredeep (Southern Italy) from recording by SAPTEX temporary array. Ann. Geophys 48 (6), 1035-1054.

Galadini, F., Meletti, C., Vittori, E.A., 2000. Stato delle conoscenze sulle faglie attive in Italia: elementi geologici di superficie: Risultati del Progetto 5.1.2 "Inventario delle faglie attive e dei terremoti ad esse associabili, in Le ricerche del GNDT nel campo della pericolosità sismica (19961999), in: Galadini, F., Meletti, C., Rebez, A. (Eds), pp. 107-136, CNR- Gruppo Nazionale per la Difesa dai Terremoti, Roma.

Gasparini, P., Iannaccone, G., Scarpa, R., 1985. Fault-plane solutions and seismicity of the Italian peninsula. Tectonophysics $117,59-78$.

Giano, S., Maschio, L., Alessio, M., Ferranti, L., Improta, L., Schiattarella, M., 2000. Radiocarbon dating of active faulting in the High Agri Valley, southern Italy. J. of Geodyn. 29, 371-386. 
484

485

486

487

488

489

490

491

492

493

494

495

496

497

498

499

500

501

502

503

504

505

506

507

508

509

510

511

512

513

514

515

Giardini, D., 1993. Teleseismic observation of the November 23 1980, Irpinia earthquake. Ann. Geofis. 36 (1), 17-25.

Haimson, B.C., Heirrick, C.G., 1986. Borehole breakouts- a new tool for estimating in situ stress? in: O. Stephansson (Ed), Proceedings International Symposium on Rock Stress and Rock Stress Measurements, pp. 271-280, Stockholm.

Heidbach, O., Tingay, M., Barth, A., Reinecker, J., Kurfeß, D., Müller, B., 2008. The 2008 release of the World Stress Map. (available online at www.world-stress-map.org)

Improta, L., Bonagura, M., Capuano, P., Iannaccone, G., 2003. An integrated geophysical investigation of the upper crust in the epicentral area of the 1980, Ms=6.9, Irpinia earthquake (Southern Italy). Tectonophysics 361, 139-169.

INGV-CNT Seismic Bulletin http://csi.rm.ingv.it

Lavecchia, G., 1988. The Tyrrhenian Apennines system: structural setting and seismotectogenesis. Tectonophysics 147, 263-296.

Lentini, F., Carbone, S., Di Stefano, A., Guarnieri, P., 2002. Stratigraphical and structural constraints in the Lucanian Apennines (southern Italy): tools for reconstructing the geological evolution. J. of Geodyn. 34 (1), 141-158.

Maggi, C., Frepoli, A., Cimini, G.B., Console, R., Chiappini, M., 2009. Recent seismicity and crustal stress field in the Lucanian Apennines and surrounding areas (Southern Italy): seismotectonic implications. Tectonophysics 463, 130-144.

Malinverno, A., Ryan, W.B.F., 1986. Extension in the Tyrrhenian Sea and shortening in the Apennines as a result of arc migration driven by sinking of the lithosphere. Tectonics 5, 227-245.

Mardia, K.V., 1972. Statistics of directional data, Academic Press, San Diego, California, pp. 357.

Mariucci, M.T., Amato, A., Gambini, R., Giorgioni, M., Montone, P., 2002. Along-depth stress rotations and active faults: An example in a 5-km deep well of southern Italy. Tectonics 21 (4), 1021, 10.1029/2001TC001338.

Marturano, A., Esposito, E., Porfido, S., Luongo, G., 1988. Il terremoto del 4 ottobre 1983 (Pozzuoli); attenuazione dell'intensita con la distanza e relazione magnitudino-intensita; zonazione della Città di Napoli. Mem. Soc. Geol. It. 41 (2), 941-948.

Marzocchi, W., Selva, J., Cinti, F.R., Montone, P., Pierdominici, S., Schivardi, R., Boschi, E., 2009. On the occurrence of large earthquakes: New insights from a model based on interacting faults embedded in a realistic tectonic setting. J. of Geophys. Res. 114 (B01307), doi:10.1029/2008JB005822. 
Mazzoli, S., Helman, M., 1994. Neogene patterns of relative plate motion for Africa-Europe: some implications for recent central Mediterranean tectonics. Geologische Rundschau 83, 464-468.

Mazzoli, S., Invernizzi, C., Marchegiani, L., Mattioni, L., Cello, G., 2004. Brittle-ductile shear zone evolution and fault initiation in limestones, Monte Cugnone (Lucania), southern Apennines, Italy, in: Alsop, I., Holdsworth, R.E. (Eds.), Transport and Flow Processes in Shear Zones, Geological Society, London, Special Publications 224, 353-373.

Michetti, A.M., Ferrelli, L., Esposito, E., Porfido, E., Blumetti, A.M., Vittori, E., Serva, L., Roberts G.P., 2000. Ground effects during the 9 september 1998, $\mathrm{Mw}=5.6$, Lauria earthquake and the seismic potential of the "aseismic" Pollino region in Southern Italy. Seism. Res. Let. 41 (1), 31-46.

Montone, P., Amato, A., Frepoli, A., Mariucci, M.T., Cesaro, M., 1997. Crustal stress regime in Italy. Ann. Geofis. 40 (3), 741-757.

Montone, P., Mariucci, M.T., Pondrelli, S., Amato, A., 2004. An improved stress map for Italy and surrounding regions (central Mediterranean). J. Geophys. Res. 109(B10410), doi:10.1029/2003JB002703.

Mostardini, F., Merlini, S., 1986. Appennino centro-meridionale. Sezioni geologiche e proposta di modello strutturale. Mem. Soc. Geol. It. 35, 177-202.

Pantosti, D., Valensise, G., 1990. Faulting mechanism and complexity of the 23 November, 1980, Campania-Lucania earthquake inferred form surface observations. J. Geophys. Res. 95 (B10), 15319-15341.

Pantosti, D., Valensise, G., 1993. Source geometry and long-term behavior of the 1980, Irpinia earthquake fault based on field geologic observations. Ann. Geofis. 36 (1), 41-49.

Pantosti, D., Schwartz, D.P., Valensise, G., 1993. Paleoseismology along the 1980 surface rupture of the Irpinia fault: implications for earthquake recurrence in the southern Apennines, Italy. J. Geophys. Res. 98 (B4), 6561-6577.

Patacca, E., 2007. Stratigraphic constraints on the CROP-04 seismic line interpretation, in: Mazzotti, A., Patacca, E., Scandone, P. (Eds), Results of the CROP Project sub-project CROP04 southern Apennines (Italy), Boll. Soc. Geol. It., special issue, 7, 185-239.

Patacca, E., Scandone, P., 1989. Post-Tortonian mountain building in the Apennines: The role of the passive sinking of a relic lithosphere slab, in Boriani, A. et al. (Eds), The lithosphere in Italy, Advances in Earth Science Research 80, , pp. 157-176, Acc. Naz. dei Lincei, Rome.

Patacca, E., Scandone, P., 2001. Late thrust propagation and sedimentary response in the thrust-beltforedeep system of the southern Apennines (Pliocene-Pleistocene), in: Vai, G.B., Martini, I.P. (Eds), Anatomy of an Orogen: the Apennines and adjacent Mediterranean Basins, pp. 401-440, Kluwer Academic Publishers. 
Patacca, E., Scandone, P., 2004. The Plio-Pleistocene thrust belt-foredeep system in the southern Apennines and Sicily (Southern Apenninic Arc, Italy ), in: Crescenti, U., D'offizi, S., Merlini, S., Sacchi, R. (Eds), Geology of Italy, spec. vol. Ital. Geol. Soc. IGC 32 Florence 2004, 93-129.

Patacca, E., Scandone, P., 2007. Constraints on interpretation of the CROP-04 seismic line derived from Plio-Pleistocene foredeep and thrust-sheet-top deposits, in: Mazzotti, A., Patacca, E., Scandone, P. (Eds), Results of the CROP Project sub-project CROP04 southern Apennines (Italy), Boll. Soc. Geol. It., special issue 7, 241-256.

Patacca, E., Scandone, P., Sartori, R., 1990. Tyrrhenian basin and Apenninic arcs: kinematic relations since Late Tortonian times. Mem. Soc. Geol. It. 45, 425-451.

Pescatore, T., Renda, P., Schiattarella, M., Tramutoli, M., 1999. Stratigraphic and structural relationships between Meso-Cenozoic Lagonegro basin and coeval carbonate platforms in Southern Apennines, Italy. Tectonophysics 315 (1-4), 269-286.

Pieri, P., Vitale, G., Beneduce, P., Doglioni, C., Gallicchio, S., Giano, S.I., Loizzo, R., Moretti, M., Prosser, G., Sabato, L., Schiattarella, M., Tramutoli M., Tropeano, M., 1997. Tettonica quaternaria nell'area bradanico-ionica. Il Quaternario 10, 535-542.

Plumb, R.A., Hickman, S.H., 1985. Stress-induced borehole elongation: a comparison between the four-arm dipmeter and the borehole televiewer in the Auburn geothermal well. J. Geophys. Res. 90 (B7), 5513-5521.

Plumb, R.A., Cox, J.W., 1987. Stress directions in eastern North America determined to $4.5 \mathrm{~km}$ from borehole elongation measurements. J. Geophys. Res. 92, 4805-4816.

Pondrelli, S., Morelli, A., Ekström, G., Mazza, S., Boschi, E., Dziewonski, A.M., 2002. EuropeanMediterranean regional centroid-moment tensors; 1997-2000. Phys. Earth Planet. Int. 130 (1-2), 71101.

Pondrelli, S., Salimbeni, S., Ekström, G., Morelli, A., Gasperini, P., Vannucci G., 2006. The Italian CMT dataset from 1977 to the present. Phys. Earth Planet. Int. 159 (3-4), 286-303, doi:10.1016/j.pepi.2006.07.008, available at www.ingv.it/seismoglo/RCMT.

Porfido, S., Esposito, E., Luongo, G., Maturano, A., 1988. I terremoti del XIX secolo dell'Appennino Campano-Lucano. Mem. Soc. Geol. It. 41 (2), 1105-1116.

Roure, F., Casero, P., Vially, R., 1991. Growth processes and melange formation in the southern Aoennines accretionary wedge. Earth Plan. Sci. Lett. 102, 395-412.

Scandone, P., Mazzotti, A., Fradelizio, G.L., Patacca, E., Stucchi, E., Tozzi, M., Zanzi, L., 2003. Line CROP 04: Southern Apennines, in: Scrocca, D., Doglioni, C., Innocenti, F., Manetti, P., Mazzotti, A., Bertelli, L., Burbi, L., D’Offizi, S. (Eds), Crop Atlas - Seismic reflection profiles of the italian crust, Mem. Desc. della Carta Geol. d'It. 62, 155-165. 
Schiattarella, M., Di Leo, P., Beneduce, P., Giano, I.S., 2003. Quaternary uplift vs tectonic loading: a case study from the Lucanian Apennine, southern Italy. Quaternary Int. 101-102, 239-251.

Scrocca, D., Sciamanna, S., Di Luzio, E., Tozzi, M., Nicolai, C., Gambini, R., 2007. Structural setting along the CROP-04 deep seismic profile (Southern Apennines - Italy), in: Mazzotti, A., Patacca, E., Scandone, P. (Eds), Results of the CROP Project sub-project CROP04 southern Apennines (Italy), Boll. Soc. Geol. It., special issue, 7, 283-296.

Seto, M., Utagawa, M., Katsuyama, K., Kiyama, T., 1998. In situ stress determination using AE and DRA techniques. Int. J. Rock Mech. and Min. Sci. \& Geomech. Abs. 35 (4-5), 458-459.

Shamir, G., Zoback, M.D., 1992. Stress orientation profile to $3.5 \mathrm{~km}$ depth near the San Andreas Fault at Cajon Pass, California. J. Geophys. Res. 97 (B4), 5059-5080.

Valensise, G., Pantosti, D., 2001. The investigation of potential earthquake sources in peninsular Italy: a review. J. of Seismol. 5, 287-306.

Westaway, R., Jackson, J., 1984. Surface faulting in the southern Italian Campania-Basilicata earthquake of 23 November 1980. Nature 312, 436-438.

Westaway, R., Jackson, J., 1987. The earthquake of 1980 November 23 in Campania-Basilicata (southern Italy). Geophys, J. R. Astr. Soc. 90, 375-443.

Wu, H.Y., Ma, K.F., Zoback, M.D., Boness, N., Ito, H., Hung, J.H., Hickman, S., 2007. Stress orientations of Taiwan Chelungpu-Fault Drilling Project (TCDP) hole-A as observed from geophysical logs. Geophys. Res. Let. 34, L01303, doi:10.1029/2006GL028050.

Wu, Y.H., Yeh, E.C., Dong, J.J., Kuo, L.W., Hsu, J.Y., Hung, J.H., 2008. Core-log integration studies in hole-A of Taiwan Chelungpu-fault Drilling Project. Geophys. J. Int. 174, 949-965.

Zheng, Z., Kemeny, J., Cook, N.G., 1989. Analysis of borehole breakout. J. Geophys. Res. 94, 71717182 .

Zoback, M.L., 1992. First- and second-order patterns of stress in the lithosphere: the world stress map project. J. Geophys. Res. 97 (B8), 703-728.

Zoback, M.L., Zoback, M.D., 1980. State of stress in the conterminous United States. J. Geophys. Res. 85 (B11), 6113-6156.

Zoback, M.D., Zoback, M.L., 1991. Tectonic stress field of North America and relative plate motions, in: Slemmons, D.B., Engdahl, E.R., Zoback, M.D., Blackwell, D.D., The Geology of North America. Neotectonics of North America, Geol. Soc. Am. 339-366.

Zoback, M.D., Moos, D., Mastin, L., Anderson, R.N., 1985. Well bore breakouts and in situ stress. J. Geophys. Res. 90 (B7), 5523-5530. 
Zoback, M.L., Zoback, M.D., Adams, J., Assumpçao, M., Bell, S., Bergman, E.A., Blumling, P., Brereton, N.R., Denham, D., Ding, J., Fuchs, K., Gay, N., Gregersen, S., Gupta, H.K., Gvishiani, A., Jacob, K., Klein, R., Knoll, P., Magee, M., Mercier, J.L., Müller, B.C., Paquin, C., Rajendran, K., Stephansson, O., Suarez, G., Suter, M., Udias, A., Xu, Z.H., Zhizhin, M., 1989. Global patterns of tectonic stress. Nature 341, 291-298.

\section{Figure Captions}

622

623

624

625

626

627

628

629

630

631

632

633

634

635

636

637

638

639

640

641

642

643

644

645

646

647

648

649

650

651

652

653

654

655

656

657

658

659

660

661

662

663

Figure 1. Above: schematic structural map (modified after Scrocca et al., 2007): 1. Main out of sequence thrust; 2. Buried Apenninic thrust front; 3. CROP-04 seismic line; 4. Wells. Below: part of CROP-04 cross-section (section A-A'; modified after Cippitelli, 2007 according to the stratigraphic description of Patacca, 2007 from c. to e. deposits). Legend: a. Castelgrande Sandstone (Miocene); b. Cilento Flysch and Liguride-Sicilide complex (Cretaceous-Paleogene); c. Apenninic carbonate Platform (Alburno-Cervati; late Triassic); d. Lagonegro II unit (early Triassic-early Cretaceous) e. Apulian carbonate Platform (Dogger-early Pliocene); f. Permo-Triassic substratum; g. Normal fault; h. Reverse fault-overthrust plane; i. Unconformity.

Figure 2. Regional overview of present-day stress data and seismicity. The black arrows indicate the $\mathrm{S}_{\mathrm{hmin}}$ average orientation obtained by all the stress indicators. Historical seismicity from $217 \mathrm{~B}$.C. to 1980 (M $\geq 5.5$; CPTI Working Group, 2004); instrumental seismicity from 1981 to present (INGVCNT Seismic Bulletin http://csi.rm.ingv.it); fault plane solutions of the largest earthquakes (see Table 1 for references).

Figure 3. a) Map of the Irpinia Fault System and its segments breaking at $0 \mathrm{~s}, 20 \mathrm{~s}$ and $40 \mathrm{~s}$ with the associated focal mechanism solutions. The stars represent the earthquake epicenters (modified from Pantosti and Valensise, 1990); b) zoom of the Marzano-Carpineta fault segment with the location of the San Gregorio Magno 1 well.

Figure 4. Breakout data along the San Gregorio Magno 1 well: a) synthetic stratigraphic log of the main lithological and tectonic units (Patacca, 2007); b) available data interval; c) breakout zones: the size of the black rectangle represents the length of the breakout data with the same direction; d) individual breakout azimuths; e) clockwise and anticlockwise breakout rotations with respect to the regional trend; f) and g) rose diagrams of breakout results for lithological and tectonic unit; h) total rose diagram. The light grey box represents the interval in which the borehole should intersect the Irpinia fault hypothesizing different fault dips (from $60^{\circ}$ to $75^{\circ}$ ). Legend of a): 1 . stratigraphic discontinuity; 2. normal fault; 3 . thrust fault.

Figure 5. Geological and geophysical data of the San Gregorio Magno 1 well. a) Synthetic stratigraphic log of the main lithological and tectonic units (Patacca, 2007); b) washout zones; c) downhole logs; d) breakout azimuths; e) five boxes showing the magnification of the five selected sectors (in red the anomalous trend). The light grey boxes indicate possible shear zones (A, B, C, D and E sectors). See text for the explanation of zone 1, 2, 3 and 4.

Figure 6. Present-day stress data in southern Apennines. Breakouts are relative to SGM1 and wells from Montone et al., 2004. Focal mechanisms of main earthquakes and seismic sequences are shown (the numbers refer to Table 1, see References therein). Colours correspond to different types of focal solutions: brown, normal faulting with NE-SW extension; yellow, strike-slip faulting; orange, normal faulting with strike slip component and NE-SW to E-W extension; pink, normal faulting with strike slip component and N-S to NNE-SSW extension; violet, normal faulting with strike slip component and NW-SE extension. 
Figure 7. - The cross-section (modified from Cippitelli, 2007) shows the three hypotheses of the Irpinia fault trend. If the SGM1 well crosses the Irpinia fault at $2350 \mathrm{~m}$ : i) a straight fault plane $60^{\circ}$ dipping from surface to focal depth (red fault); ii) a fault plane changing dip from $70^{\circ}$ at surface to $60^{\circ}$ in the upper kilometer (blue fault). If the SGM1 well crosses the Irpinia fault at $3800 \mathrm{~m}$ : iii) a $70^{\circ}$ dipping fault changing to $60^{\circ}$ down to focal depth (yellow fault). The red star represents the mainshock at $0 \mathrm{~s}$ and the grey area around it indicates the associated error in vertical and horizontal location of about $3 \mathrm{~km}$ and $1 \mathrm{~km}$ respectively (Bernard and Zollo, 1989). Legend: a. Castelgrande Sandstone (Miocene); b. Cilento Flysch and Liguride-Sicilide complex (Cretaceous-Paleogene); c. Apenninic carbonate Platform (Alburno-Cervati; late Triassic); d. Lagonegro II unit; (early Triassicearly Cretaceous) e. Apulian carbonate Platform (Dogger-early Pliocene); f. Permo-Triassic substratum; g. Normal fault; h. Reverse fault-overthrust plane; i. Unconformity. 
676

677

678

679

680

681

682

683

Research highlights

- Horizontal stress orientations in the well are consistent with the regional trend.

- Anomalous stress orientations reveal local stress sources

- faults cause log anomalies in a well

- fault-well intersection at depth can be defined

- downhole logs help in defining fault geometry at depth 


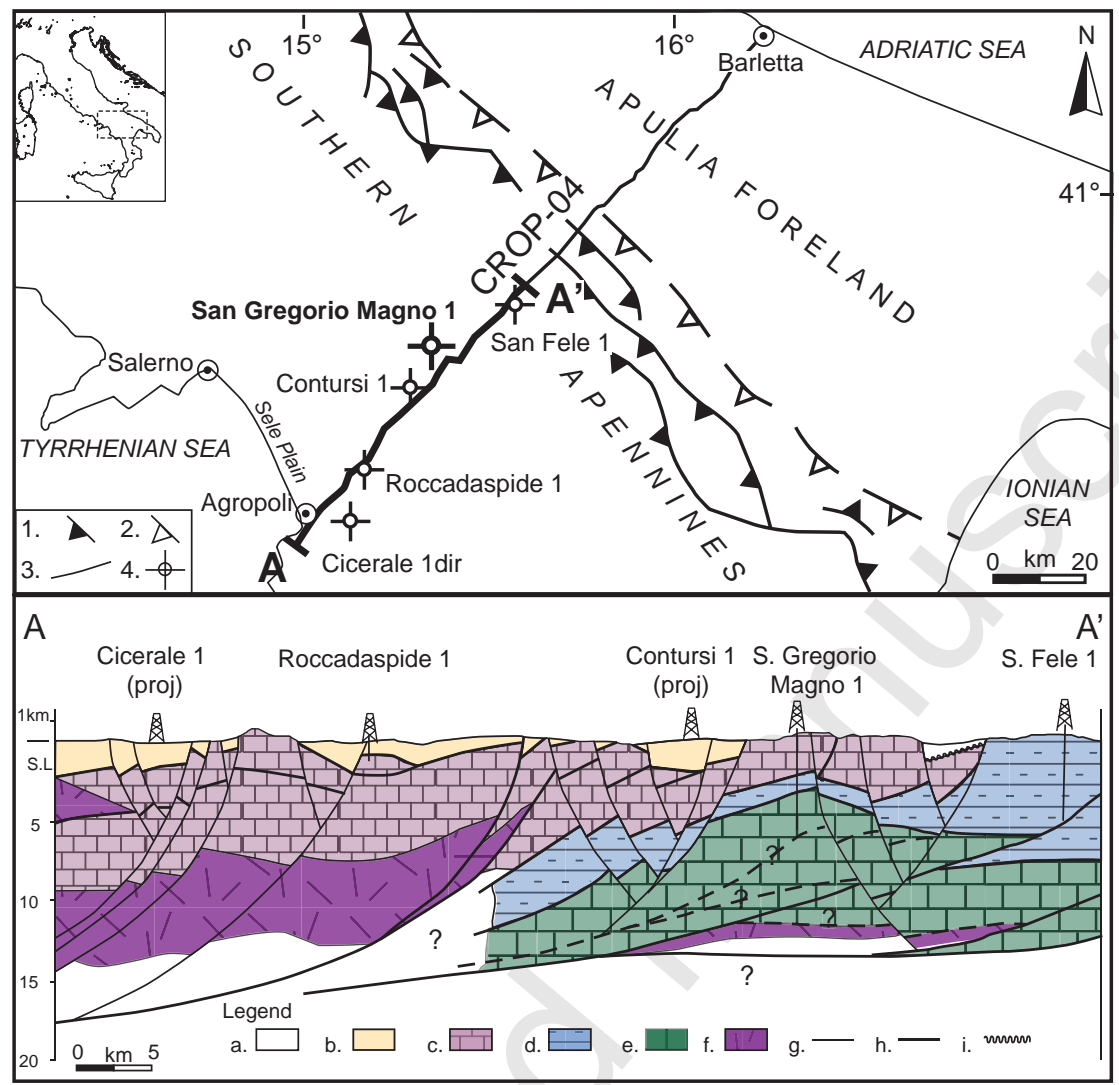

Figure 1 


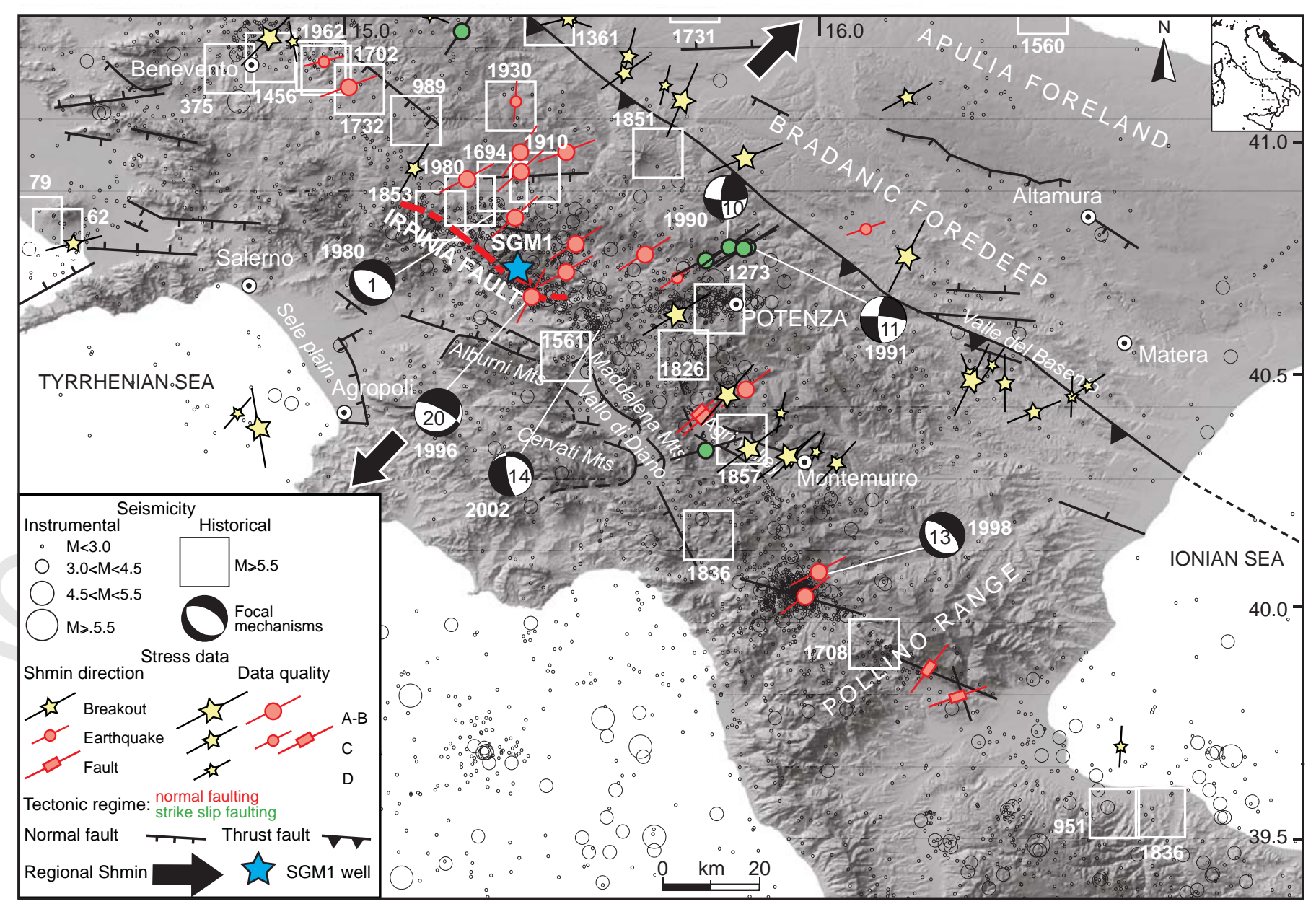

Figure 2 

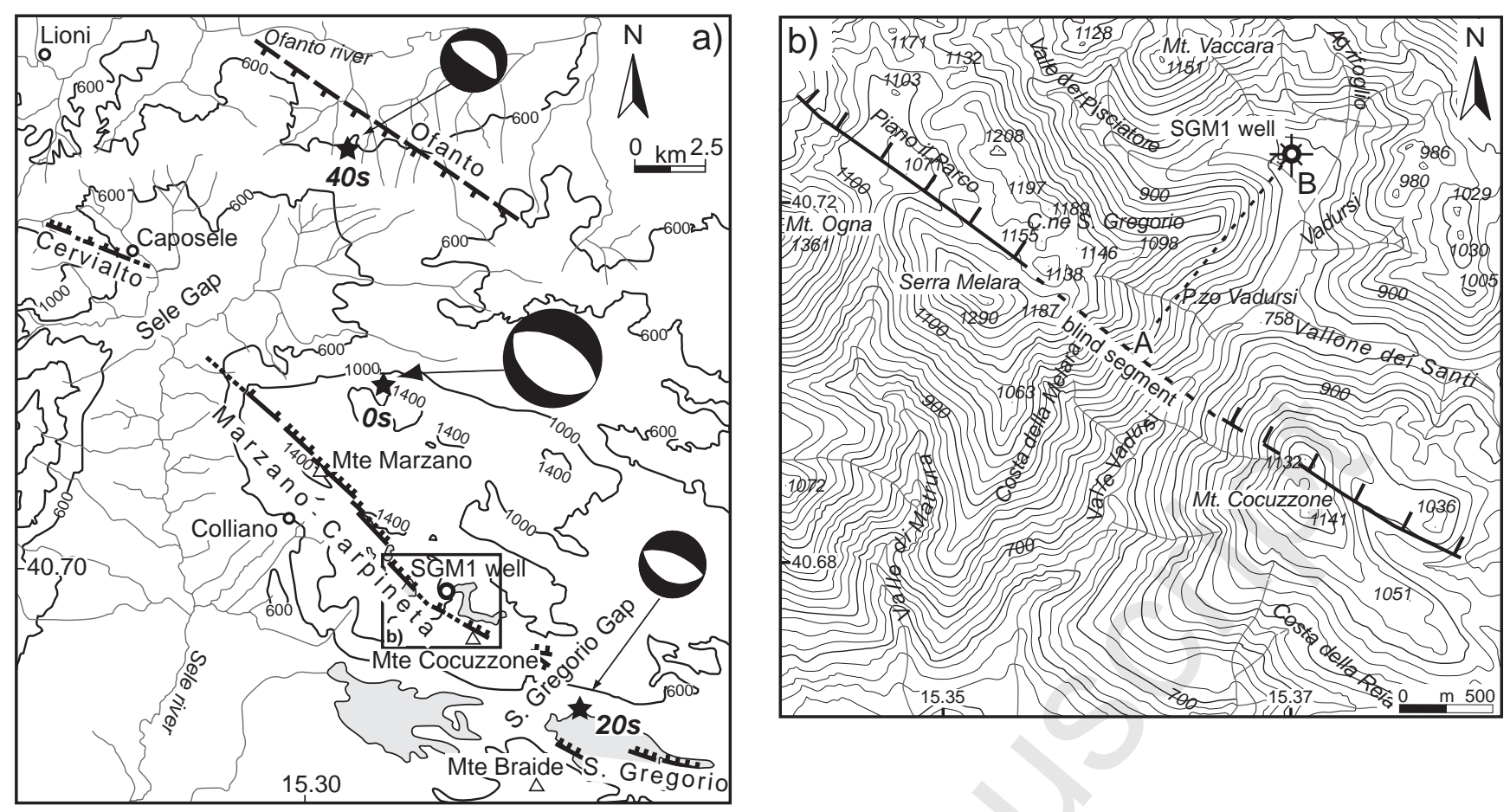

Figure 3 


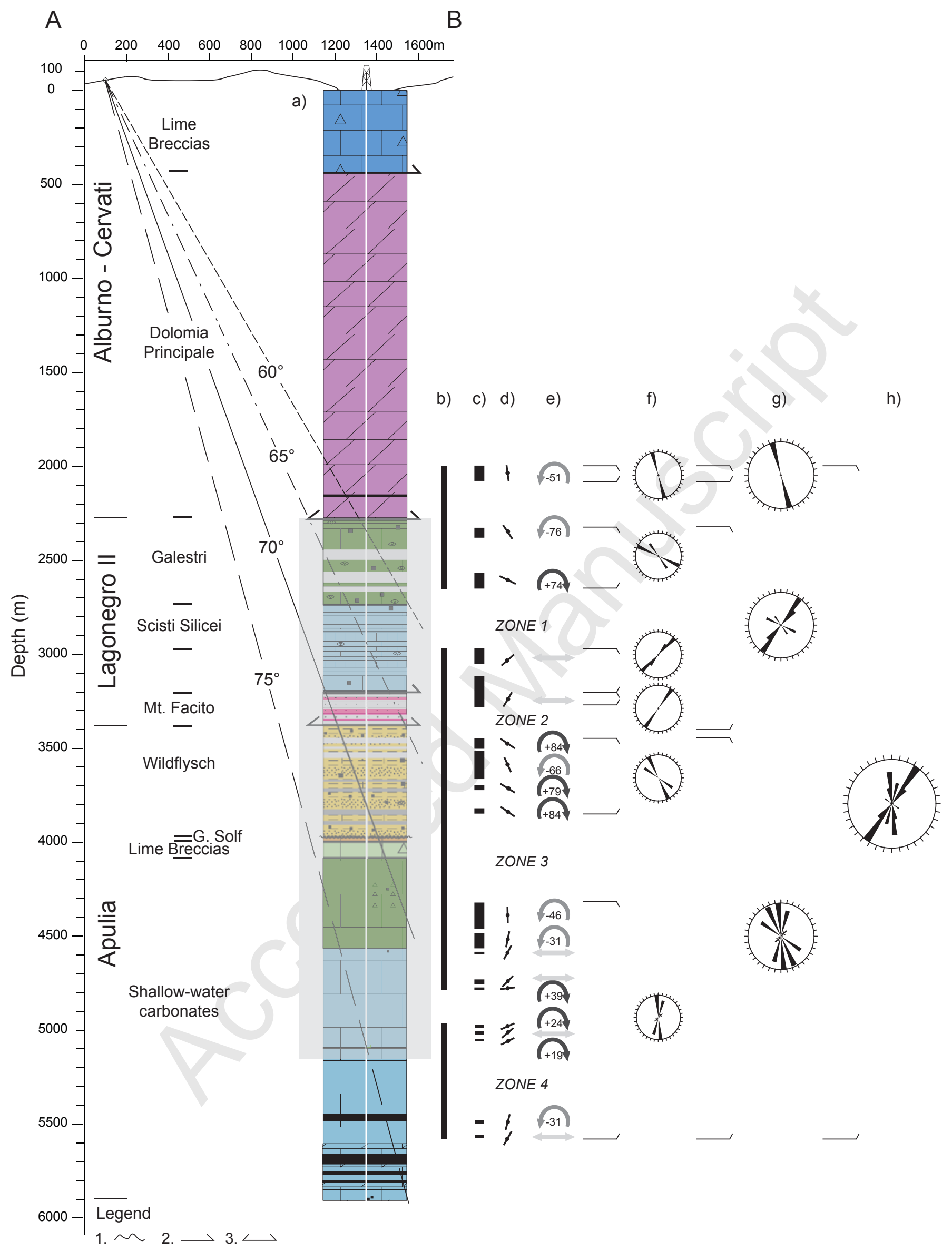

Figure 4 


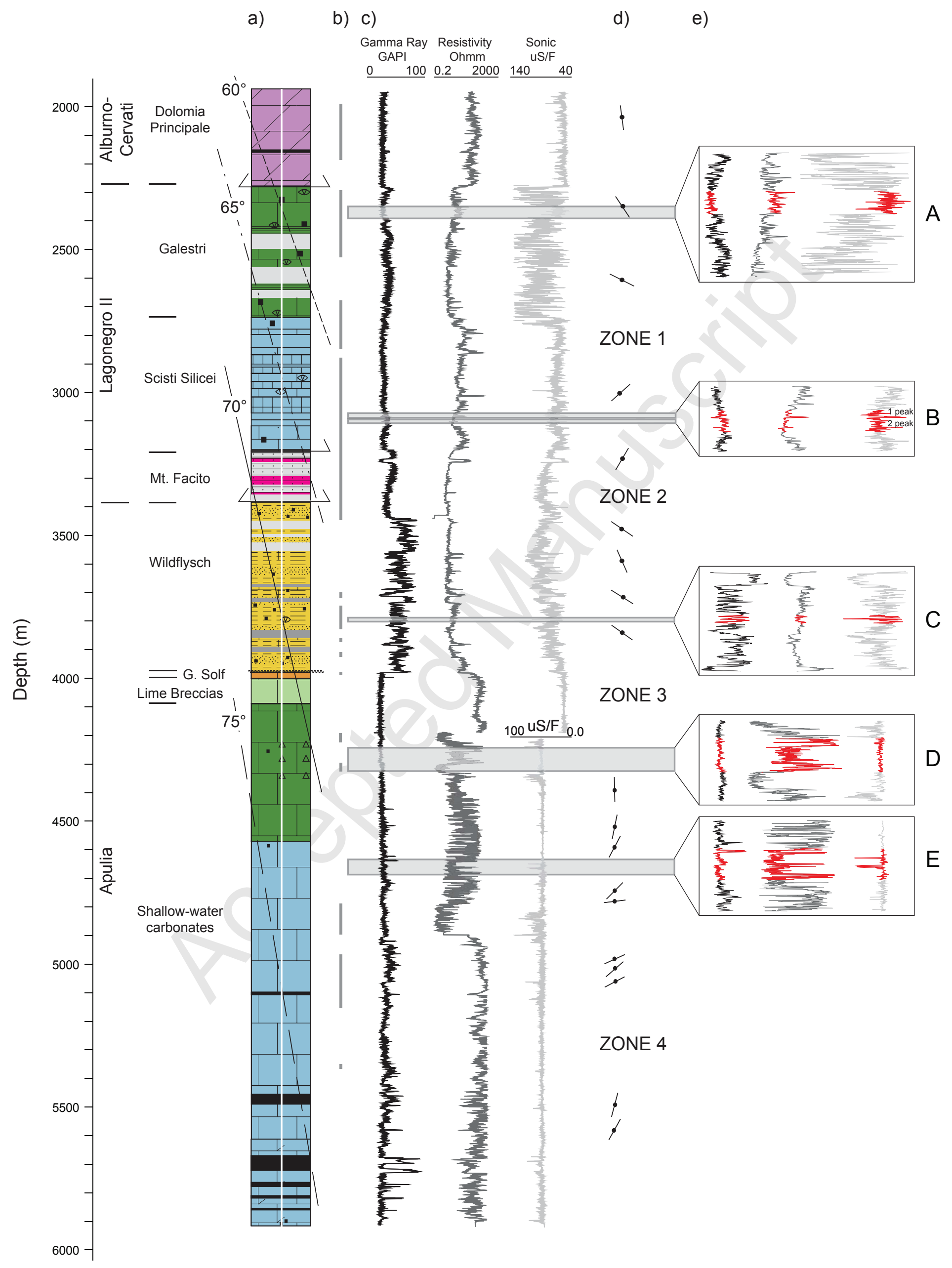




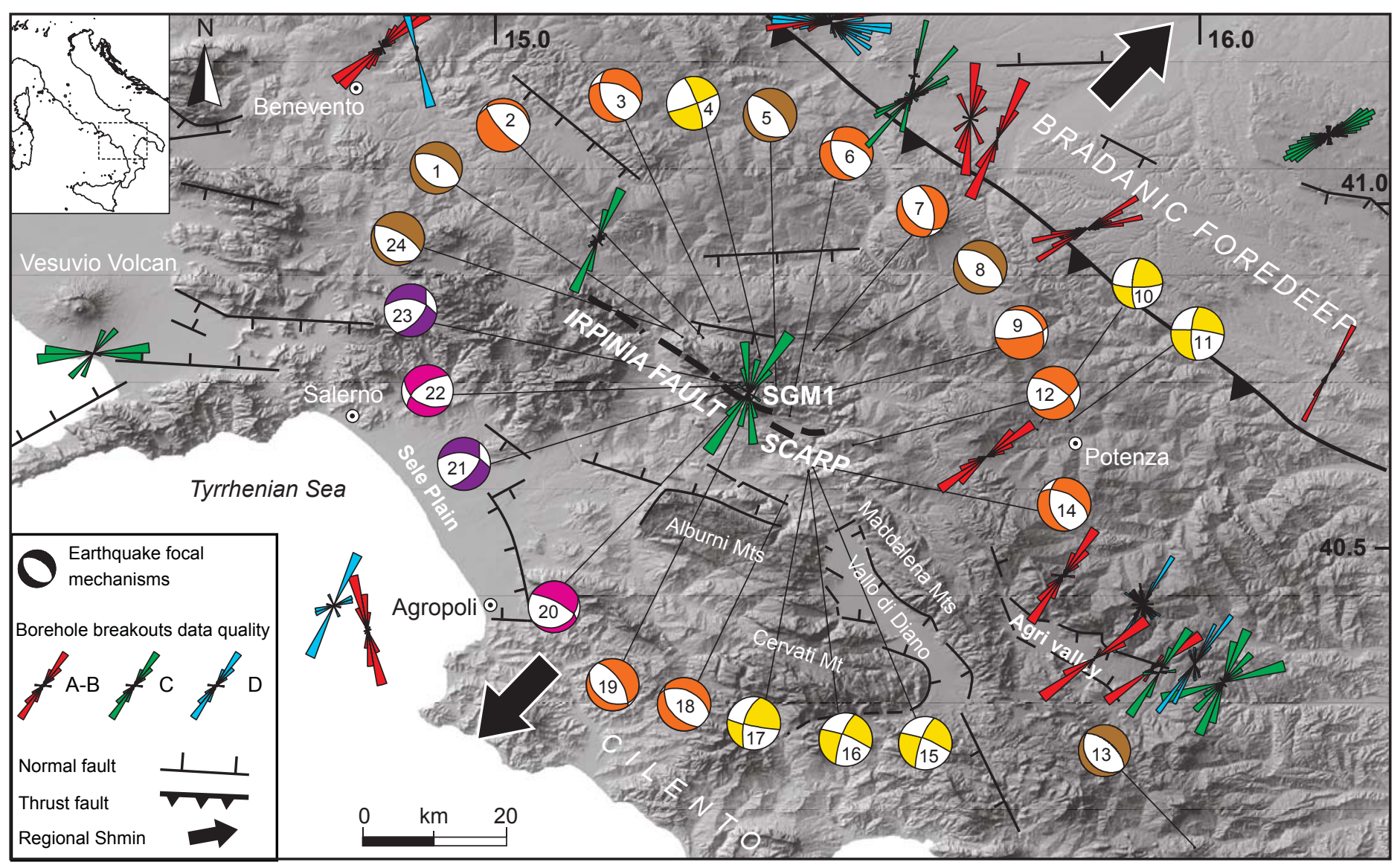

Figure 6 


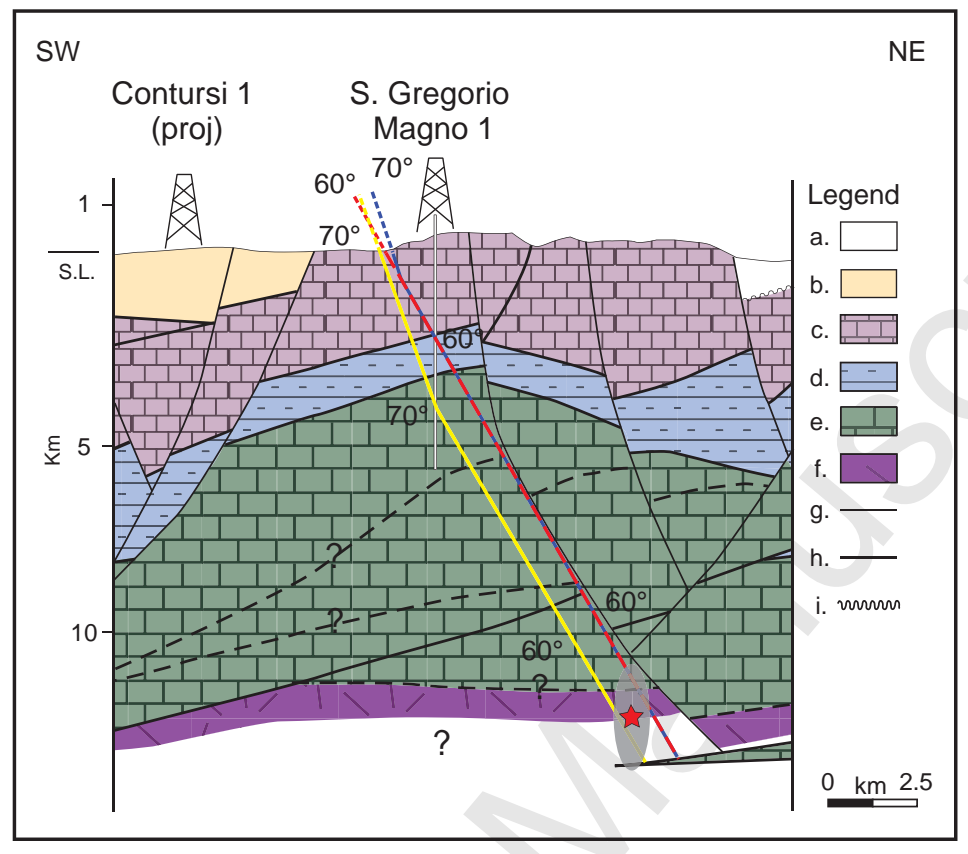

Figure 7 
Table 1

Earthquake focal mechanism data (the events are ordered according to figure 6).

\begin{tabular}{ccccccccccc}
\hline $\begin{array}{c}\text { Event } \\
\text { Number }\end{array}$ & $\begin{array}{c}\text { Event Date } \\
\text { (yyyy/mm/dd) }\end{array}$ & $\begin{array}{c}\text { Origin } \\
\text { Time }\end{array}$ & $\begin{array}{c}\text { Lat, } \\
\text { deg }\end{array}$ & $\begin{array}{c}\text { Lon, } \\
\text { deg }\end{array}$ & $\begin{array}{c}\text { Depth } \\
(\mathrm{km})\end{array}$ & Magnitude & Strike & Dip & Rake & References \\
\hline 1 & 19801123 & $18: 34$ & 40.724 & 15.373 & $10-12$ & 6.9 & 135 & 60 & -80 & $\mathrm{a}$ \\
2 & 20020102 & $02: 17$ & 40.779 & 15.417 & 15.4 & 2.8 & 140 & 75 & -80 & $\mathrm{~b}$ \\
3 & 20060314 & $03: 15$ & 40.818 & 15.326 & 10.5 & 2.7 & 155 & 50 & -60 & $\mathrm{~b}$ \\
4 & 20060915 & $17: 55$ & 40.766 & 15.384 & 16.2 & 2.4 & 70 & 85 & -170 & $\mathrm{~b}$ \\
5 & 20040224 & $05: 21$ & 40.715 & 15.407 & 16.5 & 3.8 & 135 & 25 & -90 & $\mathrm{~b}$ \\
6 & 20020504 & $09: 41$ & 40.611 & 15.537 & 15.8 & 2.3 & 160 & 45 & -50 & $\mathrm{~b}$ \\
7 & 20061201 & $15: 38$ & 40.775 & 15.460 & 15.0 & 2.7 & 130 & 40 & -120 & $\mathrm{~b}$ \\
8 & 20060717 & $16: 56$ & 40.774 & 15.490 & 8.4 & 2.5 & 125 & 40 & -90 & $\mathrm{~b}$ \\
9 & 20060926 & $16: 29$ & 40.722 & 15.455 & 7.8 & 3.0 & 80 & 75 & -110 & $\mathrm{~b}$ \\
10 & 19900505 & $07: 21$ & 40.775 & 15.766 & 15.0 & 5.7 & 184 & 73 & 13 & $\mathrm{c}$ \\
11 & 19910526 & $12: 26$ & 40.730 & 15.765 & 11.0 & 5.2 & 183 & 71 & -9 & $\mathrm{c}$ \\
12 & 20020505 & $06: 40$ & 40.373 & 15.373 & 21.6 & 1.9 & 155 & 50 & -150 & $\mathrm{~b}$ \\
13 & 19980909 & $11: 28$ & 40.150 & 15.947 & 9.0 & 5.6 & 139 & 29 & -83 & $\mathrm{~d}$ \\
14 & 20020419 & $18: 06$ & 40.595 & 15.568 & 6.0 & 4.1 & 170 & 50 & -50 & $\mathrm{~b}$ \\
15 & 20020418 & $21: 00$ & 40.588 & 15.569 & 10.3 & 3.0 & 200 & 75 & -10 & $\mathrm{~b}$ \\
16 & 20020418 & $21: 36$ & 40.583 & 15.573 & 9.6 & 2.2 & 200 & 80 & -10 & $\mathrm{~b}$ \\
17 & 20020418 & $22: 58$ & 40.583 & 15.571 & 9.5 & 2.7 & 100 & 80 & 150 & $\mathrm{~b}$ \\
18 & 20020526 & $10: 19$ & 40.549 & 15.534 & 11.4 & 2.6 & 140 & 45 & -70 & $\mathrm{~b}$ \\
19 & 19960304 & $13: 04$ & 40.670 & 15.420 & 10.0 & 4.9 & 111 & 15 & -126 & $\mathrm{f}$ \\
20 & 19960304 & $13: 04$ & 40.670 & 15.420 & 8.0 & 5.1 & 297 & 74 & -70 & $\mathrm{e}$ \\
21 & 19960717 & $09: 45$ & 40.670 & 15.400 & 10.5 & 3.5 & 35 & 55 & -140 & $\mathrm{f}$ \\
22 & 19960822 & $06: 47$ & 40.670 & 15.390 & 10.0 & 3.0 & 115 & 45 & -40 & $\mathrm{f}$ \\
23 & 19960716 & $12: 46$ & 40.670 & 15.380 & 12.2 & 3.4 & 45 & 45 & -130 & $\mathrm{f}$ \\
24 & 20011209 & $12: 15$ & 40.795 & 15.287 & 16.6 & 3.3 & 130 & 20 & -80 & $\mathrm{~b}$ \\
\hline
\end{tabular}

References: a) Boschi et al., 1981; b) Maggi et al., 2009; c) Ekström, 1994; d) Pondrelli et al., 2002; e) Cocco et al., 1999; f) Cucci et al., 2004. 
Table 2

Summary of breakout data results of the SGM1 well for each lithological and tectonic unit

\begin{tabular}{|c|c|c|c|c|c|c|c|c|c|}
\hline \multirow{2}{*}{ Tectonic Unit } & \multirow{2}{*}{$\begin{array}{l}\text { Lithological } \\
\text { Unit }\end{array}$} & \multicolumn{2}{|c|}{ Depth Units } & \multicolumn{2}{|c|}{$\begin{array}{l}\text { Breakout } \\
\text { Interval }\end{array}$} & \multirow{2}{*}{$\begin{array}{c}\text { Shmin } \\
\left(^{\circ}\right)\end{array}$} & \multirow{2}{*}{$\begin{array}{c}\text { standard } \\
\text { deviation } \\
\left(^{\circ}\right)\end{array}$} & \multirow{2}{*}{$\begin{array}{l}\text { Breakout } \\
\text { length } \\
\text { (m) }\end{array}$} & \multirow{2}{*}{$\begin{array}{c}\text { Breakout } \\
\text { zone } \\
\text { number }\end{array}$} \\
\hline & & Top & Bottom & Top & Bottom & & & & \\
\hline \multirow[t]{2}{*}{$\begin{array}{l}\text { Alburno- } \\
\text { Cervati }\end{array}$} & & 40 & 2280 & 2000 & 2075 & 348 & 0 & 75 & 1 \\
\hline & $\begin{array}{l}\text { Dolomia } \\
\text { Principale }\end{array}$ & 440 & 2280 & 2000 & 2075 & 348 & 0 & 75 & 1 \\
\hline \multirow[t]{4}{*}{ Lagonegro II } & & 2280 & 3377 & 2325 & 3275 & 038 & 33 & 365 & 5 \\
\hline & Galestri & 2280 & 2735 & 2325 & 2650 & 310 & 14 & 125 & 2 \\
\hline & Scisti Silicei & 2735 & 3198 & 2960 & 3198 & 041 & 7 & 165 & 2 \\
\hline & Monte Facito & 3198 & 3377 & 3200 & 3275 & 033 & 0 & 75 & 1 \\
\hline \multirow[t]{3}{*}{ Apulia } & & 3377 & 5901 & 3450 & 5580 & 007 & 28 & 607 & 14 \\
\hline & Wildflysch & 3377 & 3977 & 3450 & 3990 & 325 & 15 & 245 & 4 \\
\hline & $\begin{array}{l}\text { Shallow-Water } \\
\text { Carbonates }\end{array}$ & 4085 & 5901 & 4090 & 5580 & 015 & 21 & 362 & 10 \\
\hline
\end{tabular}

